Pappenheimer, A. M. (1948). On Certain Aspects of Vitamin E Deficiency. Springfield, Ill.: C. C. Thomas.

Pappenheimer, A. M. \& Goettsch, M. (193I). F. exp. Med. 53, I I.

Parrish, D. B. (1949). Ann. N.Y. Acad. Sci. 52, 25 I.

Pollock, A. W. (1854). Fmrs' Mag. (3rd Ser.), 6, 329.

Scorgie, N. J. \& Miller, W. C. (1 944). Emp. F. exp. Agric. 12, 74.

Slagsvold, L. (1925). Norsk vet. Tidsskr. 6, х61.

Turner, W. A., Meigs, E. B. \& Converse, H. T. (1936). F. biol. Chem. II4, civ.

Vawter, L. R. \& Records, E. (1947). F. Amer. vet. med. Ass. r10, I52.

Victor, J. (1934). Amer. Y. Physiol. 108, 229.

Wagener, K. (1936). Tierärztl. Rdsch. 42, 789.

Willman, J. P., Asdell, S. A., Grams, W. T. \& Hagan, W. A. (193I). Proc. Amer. Soc. Anim. Prod., p. $23 \mathrm{r}$.

Willman, J. P., Loosli, J. K., Asdell, S. A., Morrison, F. B. \& Olafson, P. (1945). F. Anim. Sci. 4, 128.

Willman, J. P., Loosli, J. K., Asdell, S. A., Morrison, F. B. \& Olafson, P. (1946). Cornell Vet. 36, 200.

\title{
The Nutrition of the Young Ayrshire Calf
}

\section{Composition of the Tissues of Normal and Dystrophic Calves}

By K. L. BLAXTER (In Receipt of a Senior Award of the Agricultural Research Council)

\author{
AND W. A. WOOD \\ Hannah Dairy Research Institute, Kirkhill, Ayr
}

(Received 27 March 195r)

In a previous paper (Blaxter, Watts \& Wood, I952) data were presented which showed that experimental diets could be prepared which, when given to young calves, caused a very high incidence of muscular dystrophy. The present paper is concerned with the composition of muscles and other tissues of these calves.

\section{General}

EXPERIMENTAL

The plan of the experiment, details of experimental animals, their diets and their management were given in the previous paper (Blaxter et al. 1952). The same nomenclature is used here, namely:

Group AO.E. Vitamins A and D were supplied in solution in arachis oil; $50 \mathrm{mg}$ $\alpha$-tocopheryl acetate were given daily.

Group AO.O. Vitamins A and D were supplied in solution in arachis oil; no vitamin $\mathrm{E}$ was given.

Group CLO.E. Vitamins A and D were supplied by cod-liver oil; $50 \mathrm{mg} \alpha$-tocopheryl acetate were given daily.

Group CLO.O. Vitamins A and D were supplied by cod-liver oil; no vitamin E was given.

Individual calves are referred to by treatment and replication number.

\section{Methods}

Post-mortem methods and details of dissections have been described (Blaxter et al. 1952). The following muscles were analysed chemically: supraspinatus, infraspinatus, 
long head of triceps, lateral head of triceps, anterior brachial, coraco-radialis, anterior extensor of the metacarpus, biceps femoris, semi-tendinosus, semi-membranosus, rectus femoris, vastus medialis, adductor, gastrocnemius, diaphragm, tongue and heart. Brain and liver were also analysed, but not in such great detail. All tissues were dissected free of tendon and fascia and were macerated in a high-speed blendor. On this fresh material water was estimated by direct drying at $100^{\circ}$; cholesterol and cholesteryl esters by the method of Schoenheimer \& Sperry (1934) as modified by Sobel \& Meyer (1945); nitrogen by Kjeldahl; acid-soluble, lipid and nucleic-acid phosphorus compounds were separated by the method of Schneider (1945) and the phosphorus was determined by the method of Fiske $\&$ Subbarow (1925), creatine by the method of Rose, Helmer \& Chanutin (I927) and collagen by the method of Spencer, Morgulis \& Wilder (1937). Non-protein and total-globulin nitrogen were determined on isotonic potassium chloride-bicarbonate extracts of the fresh muscle prepared by maceration in a high-speed blendor using tungstic acid as a precipitant. Myosin was estimated through the nitrogen content of the precipitate formed after dilution of the buffer extracts at the iso-electric point of myosin. Stroma proteins were estimated by determination of the nitrogen content of the washed residuum of the extract. On the dried muscle and tissue, fat was determined by extraction with diethyl ether and light petroleum; calcium and magnesium by the method of McCrudden (I9II-I2), iron by the method of Woiwod (1947), sodium by the method of Butler \& Tuthill (193I) and total phosphorus by the method of Fiske \& Subbarow (r925). Potassium was determined by direct weighing of the cobaltinitrite precipitate (Rowland, I948).

\section{Dry-matter content of the muscles}

\section{RESULTS}

The mean dry-matter content of the muscles is shown in Table $\mathbf{r}$. The frequency distributions presented in Fig. I show that the dry-matter content of the muscle tissues decreased, and conversely the water content increased, when the animals were given cod-liver oil as a source of vitamins $A$ and $D$ and also when vitamin $E$ was excluded from the diet. Analysis of variance of the results of Table I showed that both the effects of cod-liver oil and lack of vitamin $\mathrm{E}$ in increasing the water content of the muscle were significant at $P=0.05$. There was no significant interaction or synergistic effect between presence of cod-liver oil and absence of $\alpha$-tocopherol. In general, the fore-limbs tended to have a higher water content than the hind. This was not always true, for in some calves where a hind-limb was grossly dystrophic it had the higher water content.

From the notes made when the calves were slaughtered, the various muscles were classified according to the degree to which they showed dystrophic involvement. Normal muscles were classified in grade 1 , and severely affected muscles in grade 5 . The mean dry-matter content of muscles in each grade is shown in Table 2. The dystrophic muscles of severely affected calves contained more water than the normal muscles of the same calf. Even those muscles that appeared quite normal contained, however, less dry matter and more water than those of calves that were both clinically normal and normal at post-mortem examination.

The decrease in dry-matter content and concomitant increase in the water 
content of dystrophic skeletal muscle did not suggest that the condition was comparable to human muscular dystrophy or the muscular dystrophy of the rabbit, where

Table I. Mean dry-matter content of muscles from sixteen calves, four in each group, given different diets

\begin{tabular}{|c|c|c|c|c|}
\hline \multirow[b]{3}{*}{ Muscle } & \multicolumn{4}{|c|}{ Vitamins $A$ and D supplied by } \\
\hline & \multicolumn{2}{|c|}{ Cod-liver oil } & \multicolumn{2}{|c|}{ Solution in arachis oil } \\
\hline & $\begin{array}{l}\text { Without } \\
\text { vitamin } \mathrm{E} \\
(\%)\end{array}$ & $\begin{array}{c}\text { With } \\
\text { vitamin } \mathrm{E} \\
(\%)\end{array}$ & $\begin{array}{l}\text { Without } \\
\text { vitamin } \mathrm{E} \\
(\%)\end{array}$ & $\begin{array}{c}\text { With } \\
\text { vitamin } \mathrm{E} \\
(\%)\end{array}$ \\
\hline Supraspinatus & $18 \cdot 3$ & $19 \cdot 2$ & $20 \cdot 1$ & $2 I \cdot 0$ \\
\hline Infraspinatus & 18.6 & $19 \cdot 5$ & $20 \cdot 0$ & $2 I \cdot 0$ \\
\hline Long head of triceps & $18 \cdot 2$ & $20 \cdot 8$ & 19.8 & $2 I \cdot 4$ \\
\hline Lateral head of triceps & $18 \cdot 3$ & $19 \cdot 5$ & $20 \cdot 1$ & 20.7 \\
\hline Anterior brachial & $19 \cdot 3$ & $20 \cdot 2$ & $2 I \cdot 0$ & $2 \pi \cdot 8$ \\
\hline Coraco-radialis & $19 \cdot 2$ & $20 \cdot 3$ & 19.8 & $20 \cdot 3$ \\
\hline $\begin{array}{l}\text { Anterior extensor of } \\
\text { metacarpus }\end{array}$ & $21 \cdot 2$ & $20 \cdot 9$ & 19.7 & $2 I \cdot I$ \\
\hline Mean for anterior limb & 18.99 & $20 \cdot 06$ & 20.06 & $21 \cdot 05$ \\
\hline Biceps femoris & $19 \cdot 9$ & $19 \cdot 8$ & 20.9 & $21 \cdot 7$ \\
\hline Semi-tendinosus & $21 \cdot 5$ & $20 \cdot 9$ & $2 I \cdot 3$ & $2 I \cdot 9$ \\
\hline Semi-membranosus & $19 \cdot 6$ & $2 I \cdot 3$ & 20.7 & $21 \cdot 6$ \\
\hline Rectus femoris & 19.2 & $\times 9.9$ & $20 \cdot 4$ & $21 \cdot 8$ \\
\hline Vastus medialis & 18.9 & $2 I \cdot 4$ & $20 \cdot 3$ & $21 \cdot 3$ \\
\hline Adductor & 19.3 & 19.7 & 20.7 & $21 \cdot 0$ \\
\hline Gastrocnemius & 18.9 & $20 \cdot 6$ & 20.3 & $2 I \cdot 3$ \\
\hline Mean for posterior limb & 19.60 & 20.52 & 20.64 & $2 I \cdot 51$ \\
\hline Mean for both limbs & $19 \cdot 29$ & 20.29 & $20 \cdot 35$ & $21 \cdot 28$ \\
\hline Heart & 20.05 & 20.03 & 19.8 & I9.9 \\
\hline Diaphragm & $17 \cdot 2$ & $19 \cdot 4$ & 20.7 & $20 \cdot 8$ \\
\hline Tongue & $21 \cdot 4$ & $2 I \cdot 4$ & $22 \cdot 6$ & $25^{\circ} 0$ \\
\hline
\end{tabular}

Table 2. Mean dry-matter content of anterior-limb muscles from severely affected and mildly affected calves classified according to the involvement of the muscle

Severely affected calves

$\overbrace{\text { Extent }}^{\text {Involvement of muscle }}$ Grade*

Completely white throughout

Large white areas involving over $50 \%$ of the muscle substance

Scattered small white areas or single white areas involving less than $50 \%$ of the muscle substance

Generally pale or fibrous in appearance: no specific white areas

Apparently normal musclet

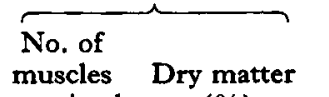

No. of
muscles

$(\%)$

I 8.10

19.02

I9.53

$19 \cdot 83$

4

$20 \cdot 20$

20. 53

10

$20 \cdot 39$

- The grading was from $I$ for a normal muscle to 5 for a severely affected one.

+ The dry-matter content of the normal muscle from anterior limbs of normal calves was $21 \cdot 05 \%$ (mean of twenty-eight determinations).

an increase in fat deposition must imply a marked fall in water content. This is well illustrated by the results of Goettsch \& Brown (1932). The triceps of normal rabbits 
contained only $I \cdot I \%$ fat and $76.5 \%$ water. The dystrophic triceps contained $34.5 \%$ fat and $50.1 \%$ water. With rats, in which dystrophy is not accompanied by extensive fat deposition, Knowlton \& Hines (1938) and Knowlton, Hines \& Brinkhous (1939) showed that an increase occurred in water content from 75.4 to $76.6 \%$. Table I

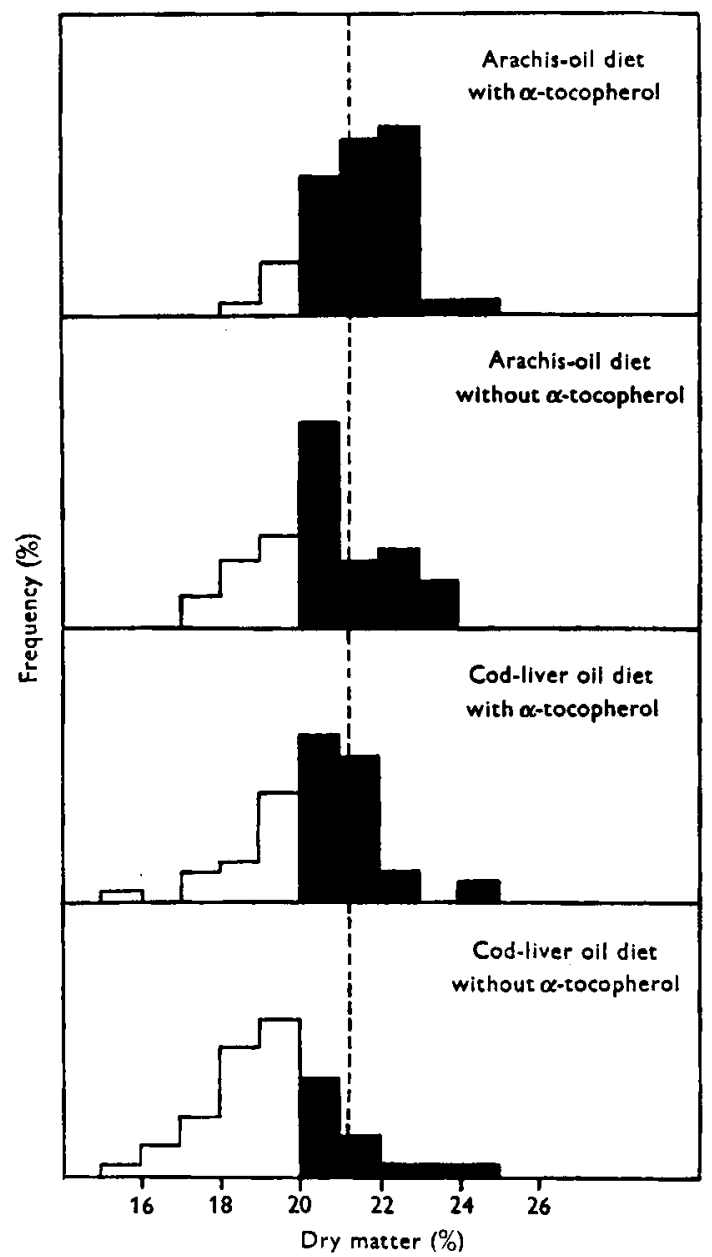

Fig. I. Percentage frequency-distributions of the dry-matter content of the muscles of calves. The dotted line is the mean content of group AO.E. Fifty-six skeletal muscles were included in each group. Black areas represent muscles containing more than $20 \%$ dry matter, a quantity which may be regarded provisionally as the lower limit of the normal.

shows the results of analyses of diaphragm and tongue muscles of the calves and indicates no major differences. Differences in the dry-matter content of the heart muscle of the calves were not statistically significant, but one high value was recorded for calf no. CLO.O. 3. The dry-matter content of the heart muscle of those animals in which evidence of abnormality had been found did not differ significantly from the mean value for their particular group. 


\section{Ash content of the muscles}

The ash content of sixteen muscles of two animals in each group was determined. Mean results are given in Table 3 .

Table 3. Mean values for two calves in each group for the ash content of the dry matter of muscles

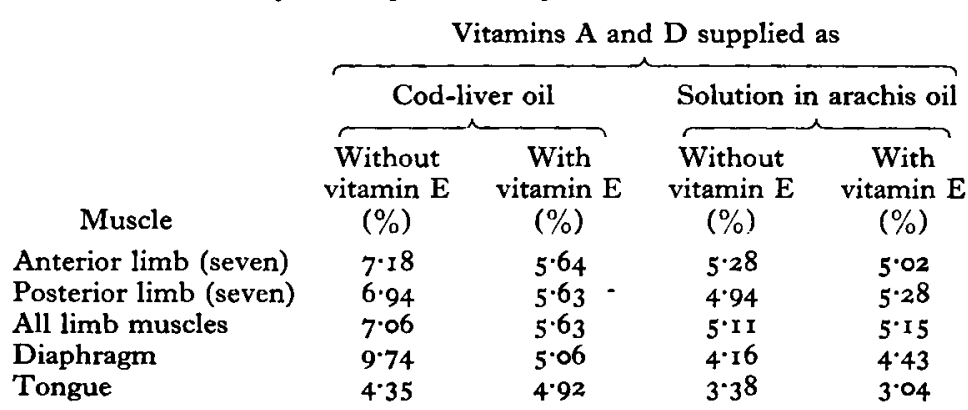

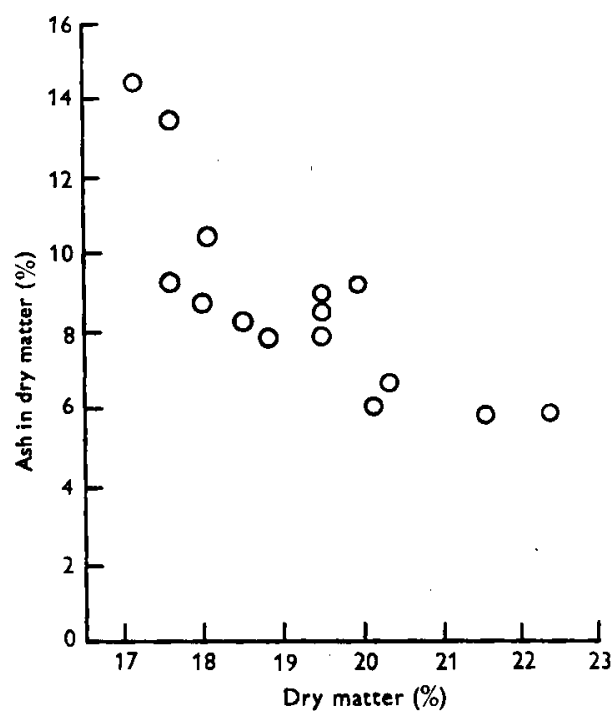

Fig. 2. Relation between the dry-matter content and the ash content of the dystrophic muscles of calf no. CLO.O. 3 .

Although the number of observations was small, statistical analysis indicated that the differences between treatment means were significant at odds of $i: I_{4}$. The concordance of the data suggest that dystrophic animals had muscles with a considerably higher ash content. Thus the highest ash content recorded for a skeletal muscle was I3.3 \% for the supraspinatus muscle of calf no. CLO.O. 3 , this muscle being a completely white muscle. The diaphragm in this animal contained $14.4 \%$ ash. In Fig. 2 the ash content of all the muscles of this calf is plotted against their dry-matter content. Where the water content of the muscle was high, the ash content of the dry matter was also high. This suggests that infiltration of electrolytes into the muscle accompanied the water infiltration. 
Analyses were then made on a number of dystrophic and normal muscles to find what minerals were present in excess in the grossly dystrophic muscles. Table 4 shows that the magnesium and phosphorus content of the muscles that were severely affected

Table 4. Calcium, magnesium and phosphorus content of selected muscles of two calves, expressed on dry weight

\begin{tabular}{|c|c|c|c|c|c|c|}
\hline Calf no. & Muscle & $\begin{array}{l}\text { Dystrophic } \\
\text { lesions }\end{array}$ & $\begin{array}{l}\text { Ash } \\
(\%)\end{array}$ & $\underset{(\mathrm{mg} / \mathrm{roO} \mathrm{g})}{\mathrm{Ca}}$ & $\underset{(\mathrm{mg} / \mathrm{roO} \mathrm{g})}{\mathrm{Mg}}$ & $\underset{(\%)}{\mathbf{P}}$ \\
\hline CLO.O. 4 & $\begin{array}{l}\text { Biceps femoris } \\
\text { Semi-membranosus } \\
\text { Heart }\end{array}$ & $\begin{array}{l}\text { Whole muscle white } \\
\text { Muscle very pale } \\
\text { Normal }\end{array}$ & $\begin{array}{l}7 \cdot 99 \\
6 \cdot 48 \\
5 \cdot 18\end{array}$ & $\begin{array}{r}202 \cdot 8 \\
57 \cdot 3 \\
30 \cdot 8\end{array}$ & $\begin{array}{r}80 \cdot 0 \\
94 \cdot 9 \\
102 \cdot 2\end{array}$ & $\begin{array}{l}\mathbf{I} \cdot 08 \\
\mathbf{I} \cdot 09 \\
\mathrm{I} \cdot 08\end{array}$ \\
\hline CLO.E. 4 & $\begin{array}{l}\text { Semi-membranosus } \\
\text { Biceps femoris } \\
\text { Heart }\end{array}$ & $\begin{array}{l}\text { Normal } \\
\text { Normal } \\
\text { Normal }\end{array}$ & $\begin{array}{l}5 \cdot 12 \\
5 \cdot 11 \\
5 \cdot 38\end{array}$ & $\begin{array}{l}28 \cdot 1 \\
24 \cdot 8 \\
26 \cdot 7\end{array}$ & $\begin{array}{r}101 \cdot 0 \\
80 \cdot 7 \\
94 \cdot 2\end{array}$ & $\begin{array}{l}0.96 \\
I \cdot 02 \\
I \cdot 25\end{array}$ \\
\hline
\end{tabular}

and had a high ash content remained in the normal range, but the calcium content of severely affected muscle was nearly ten times as great as in normal muscle. This content does not represent a severe calcification, but nevertheless shows that excessive calcium deposition had occurred. Marked calcification of the muscles was demonstrated in dystrophic rabbits by Fenn \& Goettsch (1937) and by Morgulis \& Osheroff (1938). Taking their results together, it appears that in animals given diets that induced dystrophy but slowly, the calcification was the most severe. In the present calves the dystrophy may be regarded as of a more acute nature, and the absence of extreme calcification supports the contention that only in chronic dystrophy does calcification become severe.

Table 5. Mean water content and mean sodium, potassium and creatine content of normal and dystrophic muscles of calves, expressed on dry weight

\begin{tabular}{|c|c|c|c|c|c|c|c|c|}
\hline \multirow[b]{2}{*}{ Muscle } & \multirow[b]{2}{*}{$\begin{array}{l}\text { No. of } \\
\text { samples }\end{array}$} & \multirow[b]{2}{*}{$\begin{array}{l}\text { Water } \\
(\%)\end{array}$} & Creatine & $\mathrm{Na}$ & $\mathbf{K}$ & $\mathrm{Na}$ & $\mathrm{K}$ & $\begin{array}{l}\text { Total } \\
\mathrm{Na}+\mathrm{K}\end{array}$ \\
\hline & & & \multicolumn{3}{|c|}{$(\mathrm{mg} / \mathrm{roog})$} & \multicolumn{3}{|c|}{ (mg equivalents $/ 1$ muscle water) } \\
\hline $\begin{array}{l}\text { 'Normal' from calves in } \\
\text { group AO.E. }\end{array}$ & 4 & $77 \cdot 9$ & $45 I$ & 一 & 1917 & - & $134 \cdot 8$ & - \\
\hline $\begin{array}{l}\text { 'Normal'* from affected } \\
\text { calves }\end{array}$ & 5 & $78 \cdot 1$ & 445 & $30 \cdot 5$ & 1721 & $38 \cdot 5$ & $123 \cdot 2$ & $161 \cdot 7$ \\
\hline Obviously dystrophic muscle & 4 & $80 \cdot 6$ & 289 & $55^{\circ} 2$ & 1612 & $55^{\cdot 9}$ & $98 \cdot 6$ & 154.5 \\
\hline $\begin{array}{l}\text { Single very severely } \\
\text { affected musclet }\end{array}$ & $\mathbf{I}$ & $85 \cdot 0$ & 59 & $124 \cdot 0$ & 919 & $95^{\cdot 1}$ & $4 I \cdot 5$ & × 36.6 \\
\hline
\end{tabular}
affected muscle $\uparrow$

* 'Normal' refers to muscle that was classified at post-mortem examination as completely free from visible dystrophic lesions.

+ This muscle was one taken from an animal given in an unpublished experiment a diet comparable to that containing cod-liver oil. Unfortunately all comparable samples from the present series had been used when the sodium and potassium analyses were made. This muscle was comparable to the coraco-radialis of calf no. CLO.O. 2.

Sodium and potassium were determined on a series of muscles, and the mean results are given in Table 5. The dry matter of dystrophic muscle contained more sodium and less potassium than that of normal muscle. The water content of the dystrophic muscle was increased. Expressed on a water basis, the number of $\mathrm{mg}$ equivalents present as sodium increased largely at the expense of potassium, and there was an indication of a decrease in the total number of $\mathrm{mg}$ equivalents of sodium 
and potassium in the most affected muscle. These results show that major changes occurred in the distribution of water in the muscle tissues and can be interpreted as an increase in extracellular fluid and a decrease in intracellular fluid. Increases in sodium content and decreases in potassium content have been demonstrated in dystrophic rabbit muscle by Morgulis \& Osheroff (1938). It may be concluded, therefore, that with the calf, as with the rabbit, muscular dystrophy is associated with an increase in mineral content of muscle, as a result of both a mild pathological calcification and a change in the proportions of intra- and extracellular fluids of the tissue.

\section{Total lipid content of the muscles}

The mean total lipid contents of the dried muscles are shown in Table 6. There were no differences between treatments that could be judged significant. Owing to the highly variable incidence of dystrophy in the entire musculature, these muscles,

Table 6. Mean content of total lipid (ether extract) of the dry matter of skeletal muscle* and heart from four calves in each group

$\begin{array}{lcc}\quad \text { Treatment } & \text { Mean total lipid (dry basis, \%) } \\ \text { Skeletal muscle } & \text { Heart } \\ \text { Cod-liver oil diet without vitamin E } & 3.36 & 11 \cdot 3 \mathrm{r} \\ \text { Cod-liver oil diet with vitamin E } & 3.65 & 11 \cdot 77 \\ \text { Arachis-oil diet without vitamin E } & 4.96 & 11.57 \\ \text { Arachis-oil diet with vitamin E } & 2.87 & 11.64 \\ \text { Standard error of means } & \pm 0.74 & \pm 1.31\end{array}$

- The rectus femoris was analysed in each animal except calves nos. CLO.O. 3 and CLO.E. 3 where the semi-membranosus was taken.

however, were not necessarily representative of the extent of dystrophy present in the whole carcass, and, in the second half of the experiment, two muscles were taken from each animal to ascertain if the more severely affected muscle differed in total lipid content from the less affected one. In the six animals that showed dystrophic lesions, the more severely affected muscle had a mean lipid content of $3.62 \%$, whereas the less severely affected contained $2.45 \%$, and where the difference in the extent of dystrophy was the greatest, the difference in lipid content was also the greatest. The twenty-four determinations comprising all the lipid analyses (eight in the first half of the experiment and sixteen in the second) were therefore grouped according to the creatine content of the muscle (assuming creatine content to be the most reliable index of dystrophic involvement), and the mean results are given in Fig. 3. It was apparent that the most severely affected muscle contained the most lipid. This is in accordance with the histological evidence presented for the guinea-pig and the rat (Goettsch \& Pappenheimer, 193 I Pappenheimer, 1948), but the dystrophy found could hardly be classified as a lipodystrophy, since the content of lipid, though increased, was nevertheless very small.

Slight browning of the fatty deposits in certain dystrophic animals was noted, and this fat gave a brown fluorescence in ultraviolet light comparable to that found by Martin \& Moore (1939) and by Moore \& Wang (1943). No extraction of the abnormal pigment was made. 


\section{Cholesterol content of muscles}

The total, free and esterified cholesterol was determined on fresh samples of the same muscles that were later analysed for total lipid. The mean results are given in Table 7. Statistical analysis showed that the effect of deprivation of vitamin $E$ was to

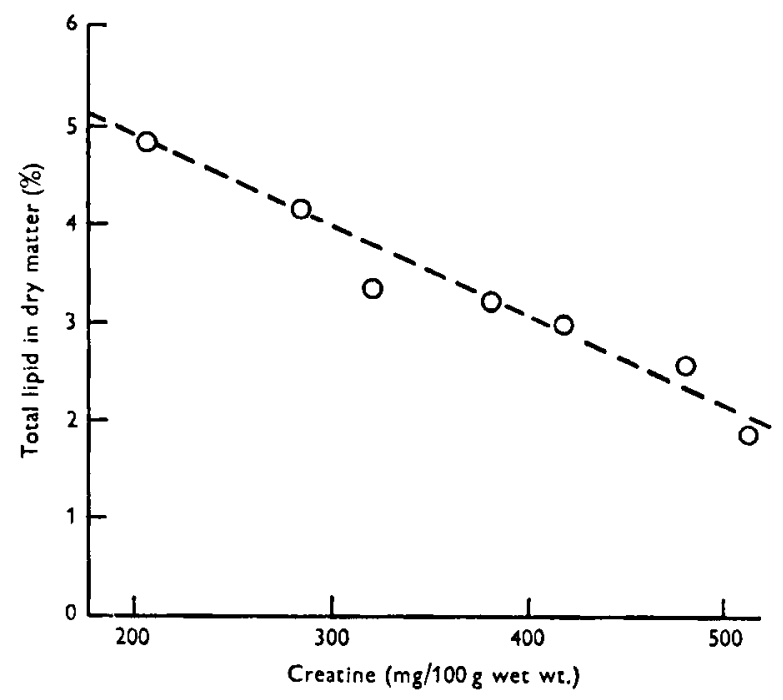

Fig. 3. Relation between the creatine content and the total lipid content of the muscles. Each point represents the mean result of simultaneous determinations of lipid and creatine content of either three or four muscles. The classification is based on creatine content. Muscles from all sixteen calves are included.

increase the total cholesterol $(P=0.05)$ and the free cholesterol $(P=0.025)$. The effect of inclusion of cod-liver oil was not statistically significant, but in only one instance did the muscle cholesterol content of the calves given cod-liver oil with vitamin $\mathrm{E}$ appear lower than that in those given arachis oil with vitamin $E$. That the cholesterol content of the dry matter of the muscle was increased in dystrophy was clearly shown by a classification of two muscles from each of six dystrophic calves, similar to that previously made for total lipid content. The results are shown in Table 8.

Table 8 shows that the most dystrophic muscles contained the most cholesterol. This appeared to be due to a large increase in free cholesterol rather than to an

Table 7. Total, free and ester cholesterol content of skeletal muscle dry-matter from four calves in each group

\begin{tabular}{lccc} 
& \multicolumn{3}{c}{ Cholesterol (mg/roog dry muscle) } \\
\cline { 2 - 4 } Treatment & Total & Free & Ester \\
il diet without vitamin E & 718 & 645 & 73 \\
il diet with vitamin E & 512 & 438 & 74 \\
diet without vitamin E & 588 & 566 & $\mathbf{2 2}$ \\
diet with vitamin E & 430 & 371 & 59 \\
rror of means & \pm 93 & \pm 83 & -
\end{tabular}

Cod-liver oil diet without vitamin $\mathrm{E}$

Cod-liver oil diet with vitamin $\mathrm{E}$

Arachis-oil diet without vitamin $\mathrm{E}$

Arachis-oil diet with vitamin $E$

$\pm 93$ 
Table 8. Mean lipid, cholesterol and cholesteryl-ester content of dystrophic musclespair comparisons on each of six dystrophic calves

\begin{tabular}{|c|c|c|c|c|c|}
\hline \multirow[b]{3}{*}{ Muscle } & \multirow[b]{3}{*}{ Lipid } & $\infty \circ \mathrm{g} \mathrm{dr}$ & & & \multirow{3}{*}{$\begin{array}{c}\text { Total } \\
\text { cholesterol as } \\
\text { percentage } \\
\text { of fat }\end{array}$} \\
\hline & & \multicolumn{3}{|c|}{ Cholesterol } & \\
\hline & & Total & Free & Ester & \\
\hline Most affected & 3620 & 666 & 604 & 62 & $18 \cdot 4$ \\
\hline Least affected & $245^{\circ}$ & 555 & 419 & 136 & $22 \cdot 6$ \\
\hline Normal* & 2280 & 455 & 398 & 57 & 19.9 \\
\hline
\end{tabular}

* Total for the comparable two muscles from each of two normal calves in the second half of the experiment.

increase in esterified cholesterol. The total cholesterol content of the fat did not change during dystrophy, so that it may be concluded that the observed increase in fat content was not solely due to an increase in cholesterol. This is not in agreement with the results obtained in dystrophic rabbits where the cholesterol content of the muscle was increased more than the total lipid content (Morgulis, Wilder, Spencer \& Eppstein, 1938). More recent work (Heinrich \& Mattill, 1943), however, has shown that with rats, even in the most severe dystrophy, the proportion of cholesterol in the total lipids increased but slightly and this change could not be judged significant. The results of Morgulis \& Spencer (1936) with rabbits, though demonstrating a large change in cholesterol content, do not provide information on this aspect. In Fig. 4 the results of the analyses of skeletal muscles for cholesterol are plotted against those for muscle creatine. Dystrophic muscles were clearly lower in creatine and higher in cholesterol content.

The cholesterol content of the heart muscle was determined and the results are given in Table 9. There were no differences that could be ascribed to treatment effects.

Table 9. Mean cholesterol content of heart muscles of sixteen calves, expressed on a dry basis

\begin{tabular}{lccc}
\multicolumn{2}{c}{ (mg/roo g dry matter) } & \multicolumn{3}{c}{ Cholesterol } \\
\cline { 2 - 4 } Treatment & Total & Free & Ester \\
diet without vitamin E & 673 & $66 \mathrm{I}$ & 12 \\
liet with vitamin E & 678 & 655 & 23 \\
diet without vitamin E & 715 & 700 & 15 \\
diet with vitamin E & $\mathbf{8 I I}$ & $\mathbf{7 5 2}$ & 68
\end{tabular}

The hearts of calves nos. CLO.O. I and CLO.E. I, which were flabby at post-mortem, contained 670 and $715 \mathrm{mg}$ free cholesterol/100 $\mathrm{g}$ dry matter. The dystrophic heart of calf no. AO.O. 4 contained $665 \mathrm{mg}$ free cholesterol/100 $\mathrm{g}$ dry matter. All these values are within the normal range. In rabbits suffering from severe dystrophy of the skeletal musculature Morgulis \& Spencer (1936) also found the heart cholesterol content normal. In rabbits it is rare to find dystrophic cardiac musculature, even though the skeletal musculature is completely affected (Goettsch \& Pappenheimer, 193I). 


\section{Nitrogen content of the muscles}

The total nitrogen content of three muscles from the anterior limb, three muscles from the posterior limb and the ventricles of the heart was determined in every calf. Mean results are given in Table Io. Analysis of variance of the data given in Table ro showed that the effect of vitamin $\mathrm{E}$ administration on the muscle nitrogen was not

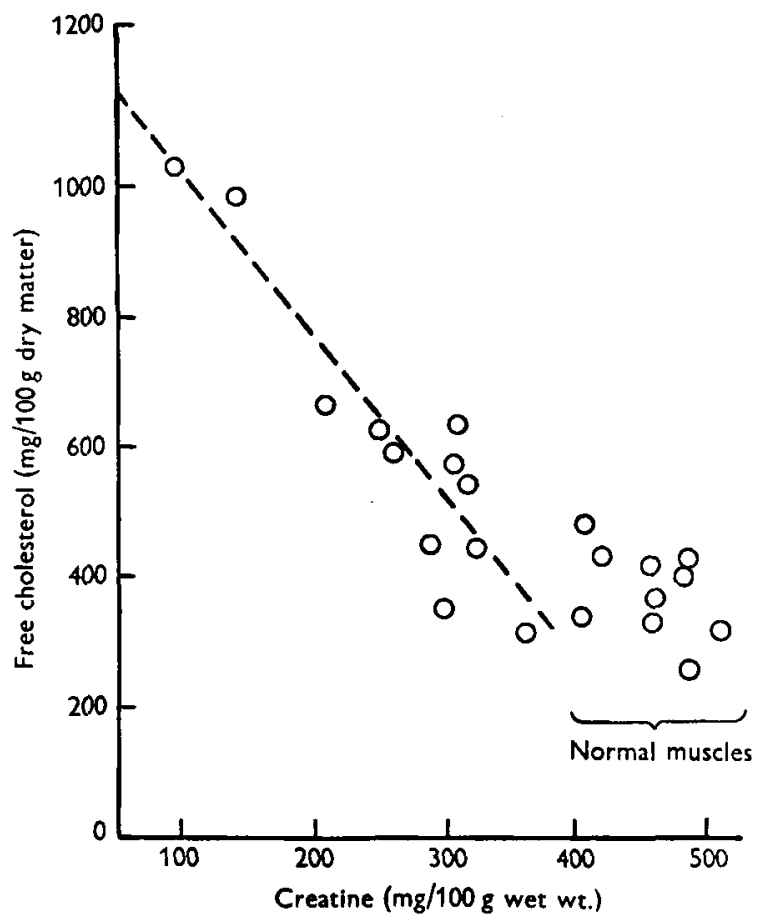

Fig. 4. Relation between the creatine content and the free cholesterol content of the muscles. Each point represents the result of a single determination of the creatine content and free cholesterol content of a skeletal muscle. Muscles from all sixteen calves are included.

significant, and the effect of cod-liver oil in reducing the nitrogen content was only significant at odds of $13: \mathrm{r}$. Nevertheless, it was suggestive that those muscles that were the most dystrophic contained the least nitrogen. The muscles were therefore classified according to extent of dystrophy as shown in Table I I. The nitrogen content of the most affected muscles was much reduced, and they contained $2.48 \mathrm{~g}$ nitrogen/roo $\mathrm{g}$ dry matter less than the normal muscles. This difference was highly significant statistically.

Eight muscles, four from normal calves and four affected muscles from dystrophic calves, were analysed for stroma protein, non-protein nitrogen and total globulin nitrogen. The percentage of the total nitrogen present as stroma proteins was increased from 22.1 to $32 \cdot 9$ in the dystrophic muscle. This increase was highly significant $(P<0.00 \mathrm{I})$. Conversely, the content of total globulin nitrogen declined. The percentage of non-protein nitrogen was not significantly affected. The decrease 
Table 10. Mean nitrogen content of skeletal and cardiac muscle of sixteen calves, four in each group, expressed on a dry basis

\begin{tabular}{|c|c|c|c|c|}
\hline \multirow[b]{3}{*}{ Muscle } & \multicolumn{4}{|c|}{ Vitamins $A$ and $D$ supplied by } \\
\hline & \multicolumn{2}{|c|}{ Cod-liver oil } & \multicolumn{2}{|c|}{ Solution in arachis oil } \\
\hline & $\begin{array}{l}\text { Without } \\
\text { vitamin } \mathrm{E} \\
(\%)\end{array}$ & $\begin{array}{l}\text { With } \\
\text { vitamin } \mathrm{E} \\
(\%)\end{array}$ & $\begin{array}{l}\text { Without } \\
\text { vitamin } E \\
(\%)\end{array}$ & $\begin{array}{c}\text { With } \\
\text { vitamin } \mathrm{E} \\
(\%)\end{array}$ \\
\hline $\begin{array}{l}\text { Supraspinatus } \\
\text { Infraspinatus } \\
\text { Long head of triceps }\end{array}$ & $\begin{array}{l}14 \cdot 76 \\
13 \cdot 94 \\
13 \cdot 90\end{array}$ & $\begin{array}{l}14 \cdot 11 \\
14 \cdot 07 \\
14 \cdot 13\end{array}$ & $\begin{array}{l}14 \cdot 58 \\
14 \cdot 83 \\
14 \cdot 37\end{array}$ & $\begin{array}{l}14.53 \\
14.38 \\
14.66\end{array}$ \\
\hline Mean for anterior $\operatorname{limb}$ & $14 \cdot 20$ & 14.10 & 14.59 & $14 \cdot 52$ \\
\hline $\begin{array}{l}\text { Semi-membranosus } \\
\text { Rectus femoris } \\
\text { Biceps femoris }\end{array}$ & $\begin{array}{l}14 \cdot 30 \\
14 \cdot 54 \\
12 \cdot 78\end{array}$ & $\begin{array}{l}13.95 \\
14.31 \\
12.89\end{array}$ & $\begin{array}{l}14.52 \\
14.69 \\
14.00\end{array}$ & $\begin{array}{l}14.90 \\
14.69 \\
14.74\end{array}$ \\
\hline Mean for posterior limb & $\times 3 \cdot 87$ & $13 \cdot 72$ & 14.40 & $14 \cdot 78$ \\
\hline Mean for both limbs" & $14.04 \pm 0.47$ & $13.91 \pm 0.47$ & $14 \cdot 50 \pm 0.47$ & $14.65 \pm 0.47$ \\
\hline Heart & $12 \cdot 85$ & $13 \cdot 30$ & 13.47 & 13.54 \\
\hline
\end{tabular}

Table I I. The nitrogen content of the muscles of the sixteen calves classified according to the involvement of the muscle

\begin{tabular}{|c|c|c|c|}
\hline Involvement of muscle & Grade* & $\begin{array}{l}\text { No. of } \\
\text { muscles } \\
\text { examined }\end{array}$ & $\begin{array}{c}\text { Mean nitrogen content } \\
\text { of musclet } \\
(\%)\end{array}$ \\
\hline $\begin{array}{l}\text { ly white throughout } \\
\text { ite areas involving over } 50 \% \text { of the } \\
\text { substance }\end{array}$ & $\begin{array}{l}5 \\
4\end{array}$ & $\begin{array}{l}5 \\
9\end{array}$ & $\begin{array}{l}11 \cdot 90 \pm 0.42 \\
13 \cdot 83 \pm 0.31\end{array}$ \\
\hline $\begin{array}{l}\text { small white areas or single white } \\
\text { volving less than } 50 \% \text { of muscle } \\
\text { ce }\end{array}$ & 3 & 13 & $14.26 \pm 0.26$ \\
\hline $\begin{array}{l}\text { pale or fibrous in appearance with } \\
\text { ific white areas }\end{array}$ & 2 & 8 & $14.06 \pm 0.33$ \\
\hline y normal & I & II & $I 4.38 \pm 0.28$ \\
\hline
\end{tabular}

in the colour of the dystrophic muscles suggested a decrease in the amount of muscle haemoglobin in the globulin fraction. Iron determinations in a series of muscles are given in Table 12. The classification of the dystrophic muscles was based on their gross appearance. It will be noted that the affected muscles contained less iron than the normal muscles. This difference was significant at $P=0.05$. The decline in the total iron of the muscles reflects a decline in muscle haemoglobin, since the amount of muscle iron present as haemosiderin, phosphocarnic acid and in other phosphate combinations is presumably small.

A further indication of the marked changes in the protein distribution of the muscles is to be found in their collagen content. The collagen-nitrogen content of normal muscles was $\mathrm{I} \cdot 8-\mathrm{I} \cdot 9 \%$ on a fresh basis. In severely affected muscles the content was increased up to $2.6 \%$. The most severely affected muscle that was analysed, the biceps 
Table 12. Mean values for total creatine content and iron content of muscles

No. of samples

Creatine content (mg/roo g wet muscle)

Iron content (mg/roo g dry muscle)

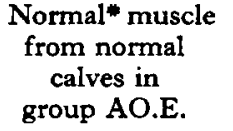

5
428

$3 \cdot 85$

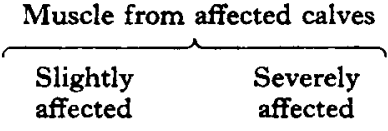

$$
\begin{array}{r}
3 \\
3 \times 8
\end{array}
$$

$3 \cdot 48$
3

$2 \cdot 60$

* 'Normal' refers to muscle that was classified at post-mortem examination as completely free from visible dystrophic lesions.

femoris of calf no. CLO.O. 4, containing only I $4 \mathrm{I} \mathrm{mg} \mathrm{creatine/100} \mathrm{g}$ fresh weight, had a collagen-nitrogen content of $3.5 \%$, which is nearly double that found in normal muscles from normal calves.

It would appear, therefore, that large changes occur in the protein fraction of the muscles, comprising a marked increase in the amount of collagen and stroma proteins, a slight fall in the non-protein nitrogen fraction and a marked decrease in the content of globulins, which, on the basis of iron determinations, appears to be due in part to a fall in the content of muscle haemoglobin. The latter would account for the white colour of the affected musculature.

\section{Creatine content of the muscles}

The creatine content of the main skeletal muscles is given in Table 13, and Fig. 5 expresses the results in the form of frequency distributions. These show that a marked decline in the creatine content of the muscles occurred both when the calves that received the arachis-oil diet were deprived of vitamin $E$ and when cod-liver oil was substituted for arachis oil. An even greater fall in the creatine content of the muscles occurred when the animals that received cod-liver oil were deprived of vitamin E. Analysis of variance of the results given in Table 13 showed that both the depressing effect of vitamin $E$ deprivation and that of cod-liver oil administration on muscle creatine were significant $(P=0.05)$. These results are in complete agreement with those of Goettsch \& Brown (I932) and Morgulis \& Spencer (1936) with rabbits and also with those of Shimotori, Emerson \& Evans (1940) with guinea-pigs and of Knowlton \& Hines (I938) with rats.

Closer examination of Table I3 shows that not all muscles were affected to the same extent. This was already evident at post-mortem examination (Blaxter et al. I952), and Table I4 summarizes typical results for calf no. CLO.E. 3 and calf no. CLO.O. 3 .

From Table 14 it can be seen that the supraspinatus muscle of calf no. CLO.O. 3 contained less creatine than the same muscle of calf no. CLO.E. 3 ; the coraco-radialis contained approximately the same amount in both calves, whereas the anterior extensor of the metacarpus of calf no. CLO.O. 3 contained more creatine than that of calf no. CLO.E. 3. A high degree of bilateral symmetry may also be inferred. Fig. 6 illustrates this symmetry. The correlation between the creatine content of muscles 
on the right side and those on the left was +0.905 , which was highly significant statistically. It was quite evident, however, that though quite symmetrical in the individual, the dystrophic lesions were not limited to particular muscles in different individuals.

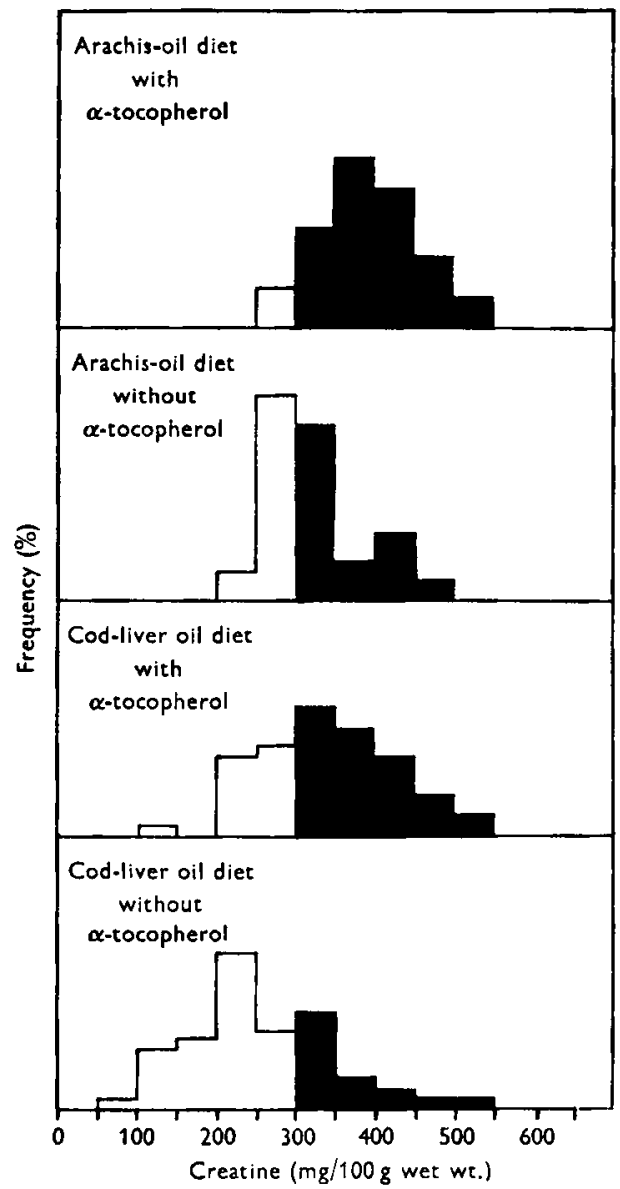

Fig. 5. Percentage frequency-distributions of the creatine content of skeletal muscles of calves (fifty-six muscles in each group). Black areas represent muscles with a creatine content greater than $300 \mathrm{mg} / \mathrm{r} 00 \mathrm{~g}$, which may be classified as normal; white areas represent muscles with a creatine content less than $300 \mathrm{mg} / \mathrm{r} 00 \mathrm{~g}$, which may be classified as abnormal.

In Fig. 7 frequency distributions are given which illustrate the accuracy of the visual classification of the muscles from dystrophic calves as far as prediction of their creatine content was concerned. There was general agreement, but the visual classification was by no means exact and there was considerable overlapping. Part of this was due to inexperience in visual classification, for, with calves that died later in the experiment, prediction was extremely good. The lowest creatine content of an affected muscle was $96 \mathrm{mg} / \mathrm{roo} \mathrm{g}$ for the completely dystrophic coraco-radialis of calf no. CLO.O. 2. 
Table 13. Mean creatine content of muscles from sixteen calves, four in each group ( $\mathrm{mg} / \mathrm{r} 00 \mathrm{~g}$ fresh weight)

Vitamins A and D supplied by

$\begin{array}{cccc}\overbrace{\text { Without }}^{\text {Cod-liver oil }} & \begin{array}{c}\text { With } \\ \text { vitamin } \mathrm{E}\end{array} & \overbrace{\text { Without }}^{\text {Wolution in arachis oil }} \\ \begin{array}{c}\text { Witho } \\ \text { vitamin } \mathrm{E}\end{array} & \begin{array}{c}\text { With } \\ \text { vitamin } \mathrm{E}\end{array} \\ 213 & 283 & 281 & 357 \\ 221 & 271 & 293 & 362 \\ 200 & 342 & 304 & 391 \\ 258 & 261 & 288 & 343 \\ 360 & 291 & 287 & 378 \\ 385 & 387 & 374 & 366 \\ 259 \cdot 9 & 347 & 283 & 386 \\ 206 & 311 \cdot 6 & 301 \cdot 4 & 369 \cdot 0 \\ 256 & 350 & 333 & 441 \\ 350 & 378 & 373 & 433 \\ 302 & 442 & 372 & 443 \\ 223 & 371 & 363 & 443 \\ 261 & 338 & 315 & 387 \\ 209 & 374 & 378 & 368 \\ 258 \cdot 1 & 316 & 279 & 383 \\ 259 \cdot 0 & 367 \cdot 0 & 344 \cdot 7 & 414 \cdot 0 \\ 239 & 339 \cdot 3 & 323 \cdot 0 & 391 \cdot 5 \\ 141 & 229 & 226 & 256 \\ 176 & 233 & 263 & 313 \\ & 219 & 221 & 239\end{array}$

Supraspinatus

Infraspinatus

Long head of triceps

Lateral head of triceps

Anterior brachial

Coraco-radialis

Anterior extensor of metacarpus

Mean for anterior limb

Biceps femoris

Semi-tendinosus

Semi-membranosus

Rectus femoris

Vastus medialis

Adductor

Gastrocnemius

Mean for posterior limb

Mean for both limbs

Heart

Diaphragm

Tongue

233

239

Table 14. Creatine content of muscles from both sides of the bodies of calves nos. CLO.E. 3 and CLO.O. 3

( $\mathrm{mg} / \mathrm{ro0} \mathrm{g}$ fresh muscle)

Calf no. CLO.E. 3

$\quad$ Muscle
Supraspinatus
Coraco-radialis
Anterior extensor of
metacarpus

$\begin{array}{cc}\text { Right side } & \text { Left side } \\ 304 & 261 \\ 504 & 516 \\ 323 & 314\end{array}$

$\overbrace{\begin{array}{c}\text { Right side } \\ 99\end{array}}^{\text {Calf no. CLO.O. } 3}$

\section{Distribution of phosphorus compounds in the muscles}

Table I 5 summarizes the results obtained by partition of the total phosphorus. A small and variable quantity of 'protein phosphorus' was ignored in the transformation of the analytical data to percentages. Analysis of variance of the results of Table I 5 showed that the differences between treatments were not statistically significant. This conclusion, however, did not apply to the differences between normal and dystrophic muscle. As shown in Fig. 8, the nucleic-acid content of muscles containing small amounts of creatine was increased. This is in close agreement with the histological evidence which showed an intense nuclear proliferation. A similar increase in the amount of lipid phosphorus was found. When the lipid phosphorus was expressed as $\mathrm{mg} / \mathrm{g}$ total lipid, the data were too variable to warrant a conclusion that the concentration of phospholipin in the fat phase had undergone any change in the dystrophic muscle. 


\section{Composition of the liver and brain}

The analytical results obtained on the brains of the sixteen calves are summarized in Table 16.

The smaller dry-matter content of the brains of the calves given cod-liver oil or deprived of vitamin $\mathrm{E}$ was significant $(P=0.05)$. This suggests that the increase in the weight of the brain in proportion to body-weight in dystrophic animals previously

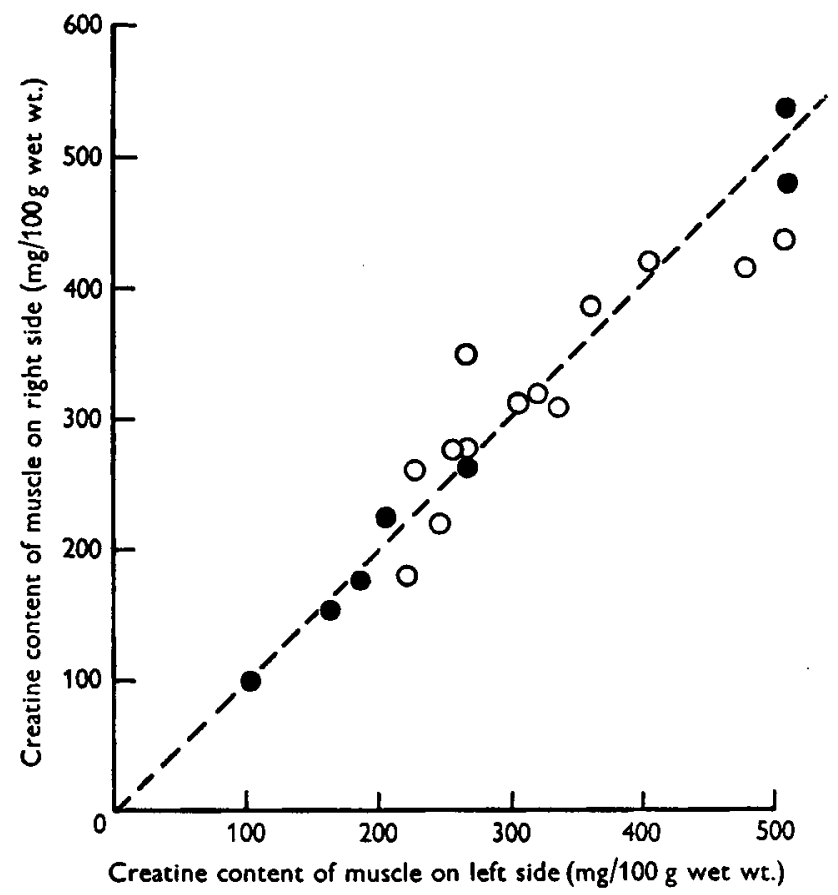

Fig. 6. Bilateral symmetry of the creatine content of the muscles. anterior limb muscles of calf no. CLO.O. 3 ; O, anterior and posterior limb muscles of calf no. CLO.E. 3 .

Table 15. Percentage distribution of total phosphorus in skeletal muscles of sixteen calves

\section{Phosphorus fraction}

Acid-soluble + inorganic phosphorus Lipid phosphorus

Nucleic-acid phosphorus

Total phosphorus ( $\mathrm{mg} / \mathrm{roo} \mathrm{g}$ muscle)

\begin{tabular}{|c|c|c|c|}
\hline \multicolumn{4}{|c|}{ Vitamins $A$ and D supplied by } \\
\hline \multicolumn{2}{|c|}{ Cod-liver oil } & \multicolumn{2}{|c|}{ Solution in arachis oil } \\
\hline $\begin{array}{l}\text { Without } \\
\text { vitamin E }\end{array}$ & $\begin{array}{c}\text { With } \\
\text { vitamin } E\end{array}$ & $\begin{array}{l}\text { Without } \\
\text { vitamin } E\end{array}$ & $\begin{array}{l}\text { With } \\
\text { vitamin }\end{array}$ \\
\hline $66 \cdot I$ & 64.4 & $72 \cdot 4$ & $74 \cdot 3$ \\
\hline $\begin{array}{l}22 \cdot 1 \\
I \mathrm{I} \cdot 8\end{array}$ & $\begin{array}{l}22 \cdot 3 \\
12 \cdot 6\end{array}$ & $\begin{array}{l}15 \cdot 3 \\
12 \cdot 3\end{array}$ & $\begin{array}{r}17 \cdot 1 \\
8 \cdot 6\end{array}$ \\
\hline 1103 & 1075 & 949 & 926 \\
\hline
\end{tabular}

reported (Blaxter et al. 1952) was due to water. There was not an exact correlation, however, between the water content of the brain and the water content of muscle. Thus the brain of calf no. AO.E. I contained $19.5 \%$ dry matter and that of calf no. AO.O. I contained $19.3 \%$. Their skeletal musculature, however, contained $21 \cdot 2$ and 
I $8.8 \%$ dry matter, respectively. The total lipid content of the brain was not affected by treatment. It would appear, however, that the cholesterol content of the brain was less in the dystrophic animals. Statistical analysis showed that this effect was not significant. The mean composition of the livers of the calves is given in Table 17 .

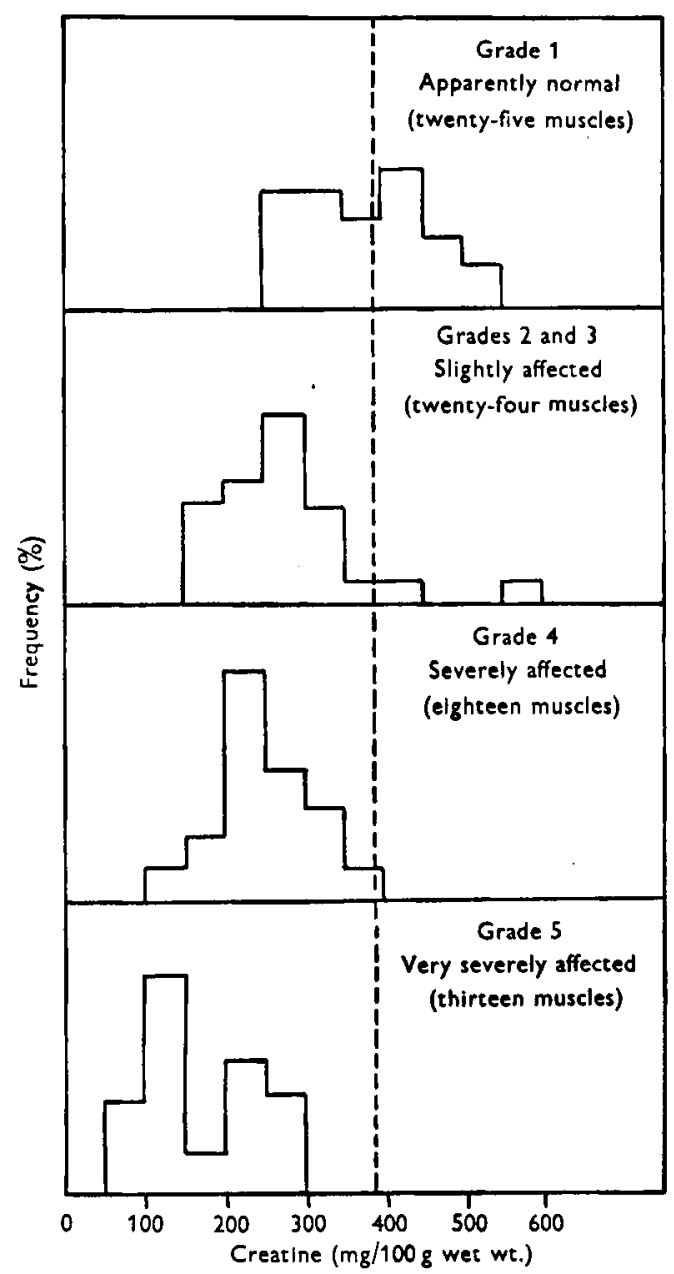

Fig. 7. Percentage frequency-distributions of the creatine content of muscles from dystrophic calves, classified according to the dystrophic involvement of the muscle. The dotted line represents the mean muscle-creatine content of normal calves. The frequency distribution at the top of the diagram may be compared with the distribution of muscle creatine of normal calves, given in Fig. 5 .

The livers of those calves given $\alpha$-tocopherol contained more dry matter than those of calves deprived of vitamin $\mathrm{E}$. The livers of the calves given vitamins $\mathrm{A}$ and $\mathrm{D}$ in solution in arachis oil contained considerably more fat than those that received codliver oil. There was no significant difference due to vitamin $\mathrm{E}$ administration. There was no large change in the cholesterol or lipid-phosphorus content of the liver suggesting that the increase in fat content was largely the result of deposition in the liver 


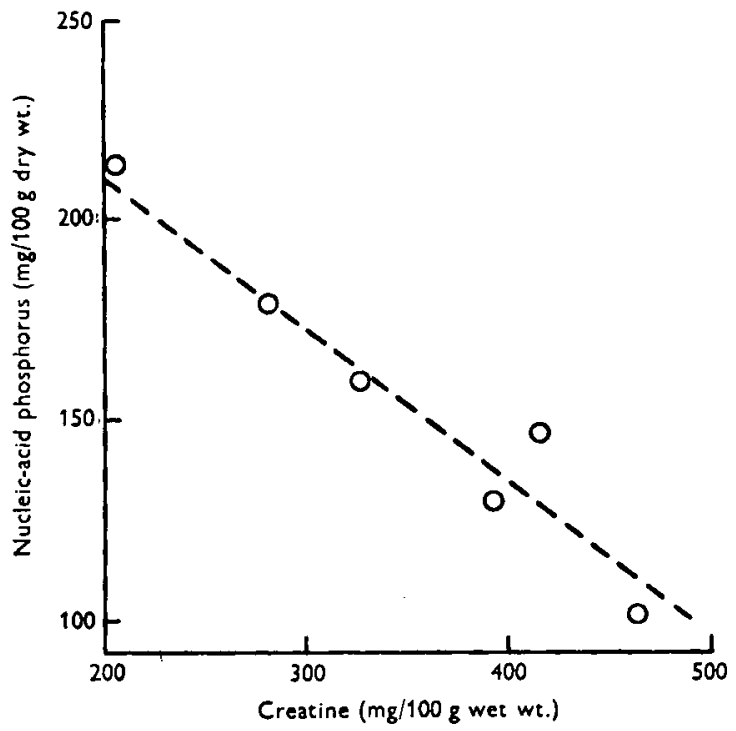

Fig. 8. Relation between the mean creatine content and the mean nucleic-acid content of muscles. Each point represents the mean result of either four or five simultaneous determinations of nucleicacid, phosphorus and creatine content of skeletal muscles. Muscles from all sixteen calves are included.

Table I6. Mean dry-matter content and mean content expressed on the dry basis of total lipid, cholesterol, lipid and total phosphorus of the brains of the sixteen calves, four in each group

Vitamins $A$ and D supplied as

$\begin{array}{cccc}\text { Cod-liver oil } & \text { Solution in arachis oil } \\ \begin{array}{c}\text { Without } \\ \text { vitamin E }\end{array} & \begin{array}{c}\text { With } \\ \text { vitamin E }\end{array} & \begin{array}{c}\text { Without } \\ \text { vitamin E }\end{array} & \begin{array}{c}\text { With } \\ \text { vitamin E }\end{array} \\ 18.41 & 18.46 & 18.74 & 19.29 \\ 43.5 & 41.5 & 43.4 & 42.7 \\ 8.4 & 8.7 & 9.4 & 10.7 \\ 627 & 447 & 499 & 510 \\ 1.6 & 1.4 & 1.5 & 1.5 \\ 19.3 & 20.9 & 21.6 & 25.0 \\ 14.4 & 10.8 & 11.5 & 12.0\end{array}$

Table 17. Mean dry-matter content and mean content expressed on the dry basis of total lipid, cholesterol, lipid and total phosphorus of the livers of the sixteen calves, four in each group

Dry matter (\%)

Total lipid (\%)

Cholesterol (\%)

Lipid phosphorus (mg/roo g total lipid)

Total phosphorus (\%)

Vitamins $A$ and D supplied by

\begin{tabular}{|c|c|c|c|}
\hline \multicolumn{2}{|c|}{ Cod-liver oil } & \multicolumn{2}{|c|}{ Solution in arachis oil } \\
\hline $\begin{array}{l}\text { Without } \\
\text { vitamin E }\end{array}$ & $\underset{\text { vitamin }}{\text { With }}$ & $\begin{array}{l}\text { Without } \\
\text { vitamin E }\end{array}$ & $\begin{array}{c}\text { With } \\
\text { vitamin E }\end{array}$ \\
\hline 24.19 & 24.50 & 23.97 & 25.64 \\
\hline $\begin{array}{l}3.85 \\
0.92\end{array}$ & $\begin{array}{l}5.35 \\
0.04\end{array}$ & $\begin{array}{l}9.82 \\
1.15\end{array}$ & $\begin{array}{l}7.64 \\
1.04\end{array}$ \\
\hline 378 & $37 x$ & 363 & 319 \\
\hline $1 \cdot 28$ & $1 \cdot 22$ & $1 \cdot 22$ & 1.06 \\
\hline
\end{tabular}


of neutral fat. Such deposition did not appear in any way related to the incidence of dystrophy and probably reflected the greater terminal failure of appetite in the calves given cod-liver oil.

\section{DISCUSSION}

The results of analyses of the muscles support the conclusions reached in the previous paper (Blaxter et al. 1952) that a dietary deficiency of $\alpha$-tocopherol results in muscular dystrophy; that the inclusion of cod-liver oil leads to an exacerbation of the disease and that only $15-18 \mathrm{ml}$. cod-liver oil is sufficient to render ineffective the protective action of a daily supplement of $50 \mathrm{mg} \mathrm{DL}-\alpha$-tocopheryl acetate. These conclusions, however, were only statistically valid where the means of a large number of analyses for each calf were examined. Where only one or two muscles from each calf were analysed, statistical treatment of the resultant means often failed to show significance at the $5 \%$ level. This is but a reflexion of the considerable variation in intensity and incidence of dystrophic lesions in the muscles of the affected individual. Analyses for constituents other than creatine, dry matter and ash were generally made on the biceps femoris. In several calves this muscle was normal in appearance, and, as the creatine analyses subsequently showed, not necessarily representative of the carcass as a whole. The results, however, may be used to demonstrate differences between normal and dystrophic musculature by methods involving cross classification, and it is with these differences, irrespective of treatment group, that this discussion is concerned.

Comparison of our results for dystrophic calf muscle with published analyses of dystrophic muscles from other animal species has already been given. The results with the calf demonstrate that the contents of ash, sodium, calcium, fat, cholesterol, nucleic acid, stroma protein, collagen and lipid phosphorus of dystrophic muscle were higher than in the normal, whereas the dry-matter, potassium, total nitrogen, globulin nitrogen, iron and creatine contents were lower in affected muscle. Such data are difficult to interpret, for they are expressed as percentages, and thus a change in the concentration of only one component must necessarily involve a change in the concentration of the others. The increase in the percentage of cholesterol, for instance, could be due either to a gross abnormality in cholesterol metabolism or to a large decrease in the amount of some other component of the muscle. The possibility exists that both interpretations may be necessary to account for the total increase. Some elucidation is made possible by a consideration of relative changes in the composition of the muscle. With the observed increase in cholesterol it was shown that the ratio of free to esterified cholesterol, and the percentage of cholesterol in the total lipid of the muscle, were unaffected in dystrophy. The lipid phosphorus expressed as a percentage of the total lipid was similarly unaffected. Together, these results suggest that increases in the concentration of cholesterol, cholesteryl ester, lipid phosphorus and total lipid in dystrophic muscle were secondary to a major change in some other fraction. By analogous reasoning the increase in water content, which was linearly related to the increase in ash content, may be ascribed to a change in the proportion of extracellular to intracellular water. This would account for the marked increase in sodium content and the fall in potassium content. The nitrogenous fraction is more 
difficult to interpret. Expressed as a percentage of the total nitrogen, the content of stroma proteins, collagen and nucleic acid increased, whereas the globulins, creatine and muscle haemoglobin (measured through its iron content) decreased. In the previous paper (Blaxter et al. 1952) it was shown that animals deficient in vitamin E stored less body nitrogen. This suggests that the primary change in the nitrogenous constituents was a decrease in the amount of muscle globulins synthesized, and that the observed changes in concentration of stroma proteins, collagen and nucleic acid were largely the result of this fall. The conclusion that the major biochemical defect in dystrophic muscle is a decline in globulin synthesis or, more probably, an increase in globulin breakdown, has much to support it. Firstly, in one of our earlier cases a myoglobinuria was observed, and in the naturally occurring disease of weisses Fleisch (Hjärre \& Lilleengen, I936) myoglobinuria is common. Secondly, a reduction of the globulin content of the cell would result in considerable changes in osmotic equilibrium and would account for the observed changes in the electrolyte content of dystrophic muscles. Thirdly, the observed decrease in the globulin content would be sufficient to account for a large part of the increase in the total lipid content and lipid fractions. Lastly, the histological appearance of the muscle, indicating a marked loss of contractile elements followed by a proliferation of sarcolemmal tissue and slight leucocytic infiltration, is in complete agreement with the contention that the globulins of the muscle are lost in large amounts (Macdonald, Blaxter, Watts \& Wood, I952). Secondary changes undoubtedly account for the increase in the calcium content of the muscle and for at least part of the increase in nucleic-acid content.

One characteristic of dystrophic musculature in other species is the increase in its oxygen uptake in vitro. Phosphorylating enzymes have been shown to decrease in concentration, while succinic dehydrogenase shows a remarkable increase. In view of the above discussion the concentration of these enzymes may reflect the change in gross composition of the tissue rather than biochemical abnormalities of the muscle cell. In this respect it is of interest that succinic dehydrogenases are closely associated with the nucleic-acid content of the tissue, whereas phosphorylating enzymes are in general cytoplasmic.

\section{SUMMARY}

x. Data relating to the chemical composition of muscles of the calves described in a previous paper (Blaxter et al. 1952) are given.

2. The dry-matter content of dystrophic muscles was lower than that of normal muscles.

3. The ash content of dystrophic muscles was greatly increased. Those muscles that were the most seriously affected contained nearly three times as much ash as normal muscles.

4. There was a considerable calcification of the affected muscles, an increase in their sodium content and a decrease in their potassium content. The phosphorus content was slightly increased but, on the basis of only a few analyses, magnesium content remained within the normal range.

5. The total lipid content of the dry muscle increased in dystrophic muscle. The total and free cholesterol and phospholipin content of the dry muscle also increased. 
The percentage of cholesterol and phospholipin in the total lipid of dystrophic muscle, however, was unchanged.

6. The total nitrogen content of dry dystrophic muscle was less than that of normal muscle. There was an increase in the amount of collagen nitrogen and in the stroma-protein nitrogen. The total globulin nitrogen was markedly decreased, the nucleic-acid content increased and the iron content of the muscle decreased.

7. In dystrophic muscles the creatine content expressed either on a wet or a dry basis was greatly reduced. The reduction in the creatine content of the skeletal muscles was bilaterally symmetrical in the individual calf.

8 The classification of affected muscles by visual examination agreed only partly with their creatine content.

9. Statistical analysis of the analytical results confirmed the conclusions on the effect of presence of cod-liver oil and absence of vitamin $E$ in the production of muscular dystrophy.

I0. Data relating to liver and brain composition are presented.

Ir. The results are discussed, and it is pointed out that the results can be explained by a major change in the synthesis or destruction, or both, of globulins in dystrophic musculature. An increase in fat, cholesterol, lipid phosphorus, stroma protein and collagen as well as oedema of the muscle could be accounted for in this way. Secondary changes account for the calcification and part of the increase in nucleic-acid content.

Our thanks are due to Mr J. A. F. Rook for the determinations of the sodium and potassium content of the muscles. We are grateful to Miss G. Breckenridge and Miss M. Cunningham for their technical assistance.

\section{REFERENCES}

Blaxter, K. L., Watts, P. S. \& Wood, W. A. (1952). Brit. F. Nutrit. 6, 125.

Butler, A. M. \& Tuthill, E. (193I). F. biol. Chem. 93, 17r.

Fenn, W. O. \& Goettsch, M. (1937). F. biol. Chem. 120, 41.

Fiske, C. H. \& Subbarow, Y. (I925). $¥$. biol. Chem. 66, 375.

Goettsch, M. \& Brown, E. F. (1932). F. biol. Chem. 97, 549.

Goettsch, M. \& Pappenheimer, A. M. (1931). F. exp. Med. 54, I45.

Heinrich, M. R. \& Mattill, H. A. (1943). Proc. Soc. exp. Biol., N.Y., 52, 344.

Hjärre, A. \& Lilleengen, K. (1936). Virchows Arch. 297, 565.

Knowlton, G. C. \& Hines, H. M. (1938). Proc. Soc. exp. Biol., N.Y., 38, 665.

Knowlton, G. C., Hines, H. M. \& Brinkhous, K. M. (1939). Proc. Soc. exp. Biol., N.Y., $42,804$.

McCrudden, F. H. (1911-12). F. biol. Chem. ro, 187.

Macdonald, A. M., Blaxter, K. L., Watts, P. S. \& Wood, W. A. (r952). Brit. F. Nutrit. 6, r64.

Martin, A. J. P. \& Moore, T. (1939). Ұ. Hyg., Camb., 39, 643.

Moore, T. \& Wang, Y. L. (I943). Biochem. F. 37, i.

Morgulis, S. \& Osheroff, W. (1938). F. biol. Chem. 124, 767.

Morgulis, S. \& Spencer, H. C. (1936). F. Nutrit. 12, I73.

Morgulis, S., Wilder, V. M., Spencer, H. C. \& Eppstein, S. H. (1938). Ұ. biol. Chem. I24, 755.

Pappenheimer, A. M. (1948). On Certain Aspects of Vitamin E Deficiency. Springfield, Ill.: C. C. Thomas.

Rose, W. C., Helmer, O. M. \& Chanutin, A. (1927). F. biol. Chem. 75, 543.

Rowland, S. J. (1948). Private communication.

Schneider, W. C. (1945). F. biol. Chem. r6r, 293.

Schoenheimer, R. \& Sperry, W. M. (1934). F. biol. Chem. ro6, 745.

Shimotori, N., Emerson, G. A. \& Evans, H. M. (1940). F. Nutrit. 19, 547.

Sobel, A. E. \& Meyer, A. M. (1945). F. biol. Chem. 157, 255.

Spencer, H. C., Morgulis, S. \& Wilder, J. M. (1937). F. biol. Chem. r20, 257.

Woiwod, A. J. (1947). Biochem. F. 41, 39 . 